\title{
Questões curriculares e a possibilidade de sua discussão em cineclubes com profes- sores: a questão religiosa na escola pública
}

\author{
NILDA ALVES \\ ERIKA ARANTES \\ ALESSANDRA NUNES CALDAS \\ REBECA SILVA ROSA \\ ISABEL MACHADO
}

\section{Resumo}

Dentro da pesquisa "Redes educativas, fluxos culturais e trabalho docente - o caso do cinema, suas imagens e sons", com financiamento do Conselho Nacional de Desenvolvimento Científico e tecnológico (CNPq), da Fundação de Amparo à Pesquisa do Estado do Rio de Janeiro (FAPERJ) e da Universidade do Estado do Rio de Janeiro (UERJ), temos buscado compreender, através do uso de filmes, em cineclubes com professores em formação e em serviço, os 'mundos culturais' pelos quais esses praticantespensantes circulam, nas redes educativas que formam e nas quais se formam. A ideia é que esses processos de contatos múltiplos com imagens e sons trazem contribuições importantes aos currículos desenvolvidos nos cotidianos escolares. Neste artigo, detectamos e expomos os modos como adesões religiosas estão nesses 'mundos culturais' de formas variadas, muitas delas discriminadoras de alguns, e os modos como alguns desses praticantespensantes buscam contatos respeitosos com outros, nesses espaçostempos.

Palavras-chave: Redes educativas, mundos culturais, imagens e sons
Defendemos a importância dessas 'conversas', no ambiente escolar e no momento presente, na tentativa de superar ações discriminatórias diversas que vêm se tornando frequentes. 


\section{Curricular issues and the possibility of discussion in film clubs with teachers: the religious issue in public school}

\author{
NILDA ALVES \\ ERIKA ARANTES \\ ALESSANDRA NUNES CALDAS \\ REBECA SILVA ROSA \\ ISABEL MACHADO
}

\begin{abstract}
Within the research "Educational networks, Cultural flowsand Teaching work- the case of cinema, its images and sounds", financed by the Conselho Nacional de Desenvolvimento Científico e Tecnológico (CNPq), Fundação de Amparo à Pesquisa do Estado do Rio de Janeiro (FAPERJ) and Universidade do Estado do Rio de Janeiro (UERJ), we have sought to understand through these of film in cine clubs with student teacher sand teachers, the 'cultural worlds' by which these participantsthinkers circulate in the educational networks that form and in which they are formed. The idea is that these multiple contact processes with images and sounds make important contributions to the circles developed in school every day. In this article, we detect and expose the ways in which religious affiliations are in these 'cultural worlds' in different ways, many of them discriminating a few, and the ways in which some of these participantsthinkers seek respectful contacts with others, in these space times. We argue in favour of the importance of these 'talks', at school and at the present time, in an attempt to overcome many discriminatory actions that are becoming frequent.
\end{abstract}

Keywords:

Educational networks, cultural worlds, images and sounds 


\title{
Cuestiones curriculares y la posibilidad de su discusión en cineclubs con profesores: la cuestión religiosa en la escuela pública
}

\author{
NILDA ALVES \\ ERIKA ARANTES \\ ALESSANDRA NUNES CALDAS \\ REBECA SILVA ROSA \\ ISABEL MACHADO
}

\section{Resumen}

En la investigación "Redes educativas, flujos culturales y trabajo docente - el caso del cine, sus imágenes y sonidos”, con financiamiento del Conselho Nacional de Desenvolvimento Científico e Tecnológico (CNPQ), de la Fundação de Amparo à Pesquisa do Estado do Rio de Janeiro (FAPERJ) y de la Universidade do Estado do Rio de Janeiro (UERJ), buscamos comprender, a través del uso de películas, en cineclubs con profesores en formación y profesores formados los "mundos culturales" por los que estos practicantes-pensantes circulan en las redes educativas que forman y en las que se forman. La idea es que esos procesos de contactos múltiples con imágenes y sonidos traen contribuciones importantes para los currículos desarrollados en el cotidiano escolar. En este artículo, detectamos y exponemos las formas como adhesiones religiosas están en esos "mundos culturales" de formas variadas, muchas de ellas discriminadoras de algunos, y las formas como algunos de esos practicantes-pensantes buscan contactos respetuosos con otros, en esos espaciostiempos. Defendemos la importancia

Palabras-clave: Redes educativas, mundos culturales, imágenes y sonidos de esas 'conversaciones', en el ambiente escolar y en el momento presente, en el intento de superaciones discriminatorias diversas que son cada vez más frecuentes. 
projeto $^{1}$ que desenvolvemos, atualmente, parte da compreensão de que questões que estão postas hoje nos currículos praticadospensados ${ }^{2}$ nas escolas têm relações diversas e complexas com as múltiplas redes educativas que os docentes formam e nas quais são formados. Este projeto, em sua primeira fase, está sendo desenvolvido em cineclubes com professores em atividade e com estudantes de licenciaturas, em alguns municípios do estado do Rio de Janeiro - Paracambi (duas vezes), Angra dos Reis (uma vez), Nova Friburgo (uma vez) e Rio de Janeiro (duas vezes).

Nesses encontros, fazemos o registro em vídeo das 'conversas'3 realizada após a projeção do filme e, na semana seguinte, desenvolvemos um 'chat' na plataforma Moodle, quando continuamos, ampliando-as, as 'conversas' iniciadas. Os filmes escolhidos para projeção têm relação com diversas questões sociais da contemporaneidade, presentes nos tantos dentrofora das escolas: diferenças/identidades raciais; diferenças/identidades de gênero; vivências urbanas e rurais; questões de trabalho e emprego; relações com as múltiplas mídias; redes educativas de formação de docentes; as políticas governamentais em suas relações com os cidadãos; os movimentos sociais em suas reivindicações por escolas; práticas escolares e contemporaneidade.

Sabemos, por pesquisas anteriormente desenvolvidas - por este grupo e outros em outras universidades brasileiras - com os cotidianos das redes educativas, que essas questões podem ser diferentemente tratadas, questionadas, interrogadas, incorporadas, ignoradas e mesmo negadas. No entanto, através dos praticantespensantes dos cotidianos, que mantêm contatos diferenciados entre si nas redes educativas que formam e nas 
quais se formam, vamos percebendo que negociações de diversos tipos são necessárias e estão presentes nelas, em processos diferenciados e complexos.

Por isto mesmo, os filmes projetados, escolhidos no acervo do Laboratório Educação e Imagem (www.lab-eduimagem.pro. br), não são, necessariamente, filmes "sobre escolas, professores e estudantes" 4 . Esses apareceram também, mas junto a outros, pois essa circulação docentediscente por inúmeras redes lhes dá condições de: identificar e analisar a multiplicidade de questões que encontram nos processos pedagógicos escolares; propor possíveis 'usos' de conteúdos a artefatos tecnológicos; criar soluções diferentes para diversos espaçostempos curriculares. Assim, certa utilização caótica destes filmes nos cineclubes que formávamos, ajudou que as diversas temáticas se entrecruzassem, estimulando uma discussão variada e complexa das mesmas.

As condições para a reunião de professores e professoras - já em atividade ou em formação - foi possível porque a $\mathrm{SR}_{3}$ (Sub-Reitoria de Extensão) nos autorizou a desenvolver cursos de extensão sob a forma de cineclube ${ }^{5}$. Assim, todo o material reunido em torno das 'conversas' desenvolvidas - registros em vídeos, trocas escritas nos'chats' e textos lançados no Fórum da Plataforma Moodle - formam o "corpus" da pesquisa, junto com os próprios filmes e o que apresentam: cenas marcantes em cada um deles; ideias que desenvolvem; diálogos registrados no desenrolar de cada filme; imagens mostradas; sons articulados à história ou questão tratada; sentimentos que despertam; estética escolhida pelo seu diretor; ética expressa; os clichês presentes e sua superação etc.

\section{Sobre redes educativas, mundos culturais e fundamentalismos}

Há muito, no desenvolvimento das pesquisas nos/dos/com os cotidianos, fomos percebendo a existência e as articulações complexas de redes educativas que os seres humanos formam e nas quais se formam, em seu viver cotidiano ${ }^{6}$.

De modo interessante, assumindo a visibilidade que as diferenças e as aproximações de seres humanos adquiriram na contemporaneidade, Augé (1997) nos diz que hoje não podemos mais falar "do mundo", já que é preciso falar "dos mundos". Esse autor nos indica, então, que são três os mundos de que precisamos tratar7: a) o 'indivíduo' que "ressurge" em contrapartida aos 'coletivos' de período anterior; b) os 'fenômenos religiosos' que se expandem, com as trocas havidas em 
períodos anteriores, durante a colonização e os movimentos de libertação, mas também tanto como formas novas de controle, no período atual dos processos capitalistas, como forma de presença nos espaçostempos políticos de grupos antes invisibilizados, acrescentamos nós; c) a 'cidade', "como se o espaço urbano se fizesse portador de todas as interrogações que suscita o espaço unificado do planeta" (p. 132).

Esses processos trazem dois grandes desafios a enfrentar: o primeiro deles é o que nos mostra que ligada às crises de identidade existe uma, mais profunda, a que se pode chamar de "crise de alteridade" e que é "porque não conseguem mais elaborar um pensamento do outro que os indivíduos e os grupos se dizem em crise" (AUGÉ, 1997, p. 130).

O segundo desafio se refere a que em condições a que Augé (p. 131) chama "hipermodernidade" aquilo que é caro ao antropólogo - as realidades localizadas e simbolizadas - se obscurecem. Como no caso das pesquisas com os cotidianos tratamos também dessas 'realidades', devemos estar atentos à ideia que este autor coloca como necessária ao momento presente: "estudar a 'crise de sentidos', a 'crise de alteridade' ali onde se manifesta sob formas diversas e, eventualmente, menos esperadas" (p.131). Para nós, no grupo de pesquisa a que pertencemos, esses espaçostempos têm sido os de aparecimento e usos dos múltiplos artefatos tecnológicos que vêm se colocando como exigindo nossa atenção, pois 'têm invadido' as redes educativas e as escolas de modo avassalador. No presente projeto, o cinema nos pareceu aquele artefato que nos ajudaria, nas 'conversas' desenvolvidas, a melhor compreender os 'mundos culturais' dos docentes e o que deles é levado aos processos curriculares ${ }^{8}$.

Indo nesta direção, nossas pesquisas nos permitiram perceber que as aproximações entre os praticantespensantes dos cotidianos, vêm se dando, no presente, através de identidades diversas que assumem, relacionadas às múltiplas redes educativas em que estão envolvidos, ao lado de distanciamentos que vão aparecendo pela 'crise de alteridade' referida acima. Um dos aspectos observados é a da questão aproximação religiosa - que, aliás, é também destacada e estudada por Augé (1997), como vimos - e que leva a assumir alguns outros como 'o outro sem legitimidade' e mesmo com alta periculosidade para a crença particular de cada um.

Pudemos ver isto no projeto - entendemos que foi mesmo uma questão que insistentemente retornava eincomodava - pelo estabelecimento de certo "fundamentalismo" (GALLO e VEIGA NETO, 2009) assumido pela presença de adeptos das novas 
igrejas protestantes nos grupos. Em nosso país, essas igrejas de diferentes tendências vêm ganhando importância numérica grande e tratam de suas relações com seus fiéis em todas as esferas da vida: a religiosa, a familiar, a da representação política, a da educação etc. Como todas as religiões o fazem, aliás.

Deste modo, para aumentar sua influência e conseguir um maior número de adeptos, teve como uma de suas estratégicas, o acirrado combate "ao diabo" encarnando-o nos praticantespensantes de outras religiões, em especial, nos do candomblé, em sua diversidade, mas também na religião católica, sobretudo pelo uso que faz de imagens. Muitos devem lembrar quando, em uma violenta expressão de iconoclasmo, um pastor de uma dessas igrejas, na televisão, chutou a imagem de Nossa Senhora.

Mais recentemente, no entanto, acordos com os adeptos da religião católica têm sido garantidos por ações conjuntas entre autoridades religiosas, em diversas situações, tais como: publicação de livros didáticos ou de folhetos 'explicativos'; apoios mútuos nas casas legislativas, contra causas importantes para grupos que formam a população brasileira: ações contra o ensino laico nas escolas públicas que foi rompido, por exemplo, pela implantação no governo Garotinho no estado do Rio de Janeiro (1999-2002) de ensino religioso confessional nas escolas públicas, desenvolvido no governo de sua mulher, Rosinha Garotinho (2003-2006), que não fazendo concurso para professor em nenhuma disciplina do currículo apesar da grande falta de professores em muitas delas, realizou um para professor de ensino religioso; impossibilidade do direito ao aborto o que tem levado à morte milhares de mulheres brasileiras; as dificuldades de leis que respeitem a orientação sexual, pela escolha do parceiro de vida e de adoção de crianças etc.

Ainda, recentemente, a distribuição de uma cartilha homofóbica levou a pronunciamento da justiça que exigiu o recolhimento da mesma e a proibição de desenvolver os Fóruns de Religião que eram realizados pelo governo do estado do Rio de Janeiro9. Inúmeras outras iniciativas 'religiosas' de diversos tipos poderiam ser ainda indicadas, como a PL n. 8099/2014, do Deputado Pastor Marco Feliciano, que busca introduzir o 'criacionismo' nas escolas públicas, o que exigiu uma carta aberta da ABRAPEC (Associação Brasileira de Pesquisa em Educação de Ciências) e da CBEnBio (Associação Brasileira de Ensino de Biologia), apoiada pela ANPEd (Associação Nacional de Pós-Graduação e Pesquisa em Educação) e ABdC (Associação Brasileira de Currículo) contra esta proposta. 
Nesses movimentos, foi possível perceber o estímulo a certas ações nos espaçostempos escolares que levam ao aparecimento de tensões e ações em escolas frequentadas pelo grupo em pesquisas anteriores. Preocupavam-nos as manifestações de racismo e homofobia que esses atos curriculares indicavam, algumas vezes, e que vamos ver aparecer nos tantos dentrofora das escolas com frequência cada vez maior. Seja porque percebíamos isto, seja porque estudantes em turmas nas quais lecionávamos indicavam este problema, seja porque docentes nos indicavam "as dificuldades de aplicação das Leis referentes às culturas negras e indígenas" ${ }^{10}$ e de "lidar com esses alunos diferentes", entendemos que essas eram questões que precisavam aparecer no projeto.

No âmbito deste artigo, entretanto, trabalhamos somente com as questões relacionadas aos embates religiosos dentrofora das escolas e às possibilidades de respeitosa convivência religiosa nas escolas públicas etc. Essas questões, no entanto, é preciso dizer, se transmutam, com muita frequência em problemas raciais sérios. Ou seja, dito de outra maneira, a questão religiosa 'esconde' modos racistas de convivência agressiva. Foi o que mostrou, recentemente - em junho/2015 -, o apedrejamento de uma jovem de onze anos quando saía de um terreiro de candomblé, na Penha, subúrbio do Rio de Janeiro.

\section{As 'conversas' como lócus de pesquisas: o surgimento de imagens e narrativas a partir delas, como "personagens conceituais"}

Na corrente de pesquisa a que pertencemos e em cuja articulação contribuímos há muito - pesquisas nos/dos/com os cotidianos - fomos identificando, para desespero de alguns que pensam que o silêncio e a ordem são fundamentais para os processos curriculares cotidianos, que se conversa muito nas escolas: os estudantes e os professores conversam entre si; uns conversam com os outros; os pais também estão presentes nessas conversas, em geral, no portão das escolas; nas cozinhas das escolas, as merendeiras e outros servidores ajudam a "manter o tom" etc.

Desse modo, fomos elegendo as 'conversas' como lócus privilegiado dessas pesquisas. A compreensão de sua importância foi possível, inicialmente, com os modos como Eduardo Coutinho trabalhava com elas em seus documentários que vimos todos, há muito tempo, no grupo de pesquisa, e que foram sendo revistos durante todos esses anos. O próprio autor identifica que o que desenvolvia eram "conversas", pois 
acreditava que outras palavras - depoimento; entrevista - não caracterizariam o que fazia, trazendo uma formalidade que não lhe interessava (COUTINHO, 1997).

Em momento bem mais recente, lendo um dos livros de Borges (2009), com "conversas" registradas há muito tempo, pudemos entender como esse escritor percebia a importância desta atividade cotidiana e como era importante se perder/ ganhar tempo com ela. Na introdução, ele indicava que "uns quinhentos anos antes da era cristã", em meio a tudo o que formava/destruía as cidades gregas,

alguns gregos contraíram, nunca saberemos como, o singular costume de conversar. Duvidaram, persuadiram, discordaram, mudaram de opinião, adiaram... Sem esses poucos gregos conversadores, a cultural ocidental é inconcebível... ( p. 27)

A partir daí, atentos ao que diziam inúmeros autores, fomos percebendo que as 'conversas' formam a preocupação de muitos. Assim, Elias (1994, p. 29) sobre esta expressão humana nos cotidianos, observa:

tomemos, por exemplo, uma forma relativamente simples de relação humana, a conversa. Um parceiro fala, o interlocutor retruca. $\mathrm{O}$ primeiro responde e o segundo volta a replicar. Se considerarmos não apenas as observações e contra-observações isoladas, mas o rumo tomado pela conversa como um todo, a seqüência de ideias entremeadas, carreando umas às outras numa interdependência contínua, estaremos lidando com um fenômeno que não pode ser satisfatoriamente representado nem pelo modelo físico da ação e reação das bolas [de bilhar], nem pelo modelo fisiológico da relação entre estímulo e reação. As ideias de cada um dos parceiros podem mudar ao longo da conversa. [...] A característica especial desse tipo de processo, que podemos chamar de imagem reticular, é que, no decorrer dele, cada um dos interlocutores forma ideias que não existiam antes ou leva adiante ideias que já estavam presentes. Mas a direção e a ordem seguidas por essa formação e transformação das ideias não são explicáveis unicamente pela estrutura de um ou outro parceiro, e sim pela relação entre os dois. E é justamente esse fato de as pessoas mudarem em relação umas às outras e através de sua relação mútua, de se estarem continuamente moldando e remoldando em relação umas às outras, que caracteriza o fenômeno reticular em geral. 
Sobre essa mesma preocupação central com as relações entre os que conversam no transcorrer das conversas, Larrosa (2003, p. 212) escreveu:

nunca se sabe aonde uma conversa pode levar...uma conversa não é algo que se faça, mas algo no que se entra...e, ao entrar nela, pode-se ir aonde não havia sido previsto...e essa é a maravilha da conversa...que, nela, pode-se chegar a dizer o que não queria dizer, o que não sabia dizer, o que não podia dizer... E, mais ainda, o valor de uma conversa não está no fato de que ao final se chegue ou não a um acordo [...] pelo contrário, uma conversa está cheia de diferenças e a arte da conversa consiste em sustentar a tensão entre as diferenças.

Por fim, com Maturana (1997, p. 132), pudemos perceber que nossas redes educativas são, sobretudo, 'redes de conversações' já que:

como animais linguajantes, existimos na linguagem, mas como seres humanos existimos (trazemos nós mesmos à mão em nossas distinções) no fluir de nossas conversações", e todas as atividades acontecem como diferentes espécies de conversações. Consequentemente, nossos diferentes domínios de ações (domínios cognitivos) como seres humanos (culturas, instituições, sociedades, clubes, jogos, etc.) são constituídos como diferentes redes de conversações, cada uma definida por um critério particular de validação, explícito ou implícito, que define e constitui o que a ela pertence.

Porque todos os momentos de viver são cotidianos e neles formamos redes que nos formam nas nossas relações, quer em nossos espaçostempos escolares, quer nos espaçostempos das ciências, seus praticantespensantes têm nas "conversas" momentos permanentes de ser humano.

Após esta compreensão, começamos a nos indagar, o que aquilo que acumulávamos nessas "conversas" era. Nelas, surgiam narrativas de muitas histórias guardadas nas memórias de tantas situações cotidianas vividas - sempre atualizadas com o passar do tempo. Surgiam também imagens, com os registros que fazíamos deles, mas também trazidas por aqueles com quem conversávamos: de ocasiões vividas nas redes educativas, com seus acontecimentos e seus praticantespensantes.

Inicialmente, pensamos que todo esse material formava o que é chamado de "fontes" (ALVES, 2008). Mas, em seguida, 
entendemos, com a leitura de Deleuze e Guattari (1992), que se tratava de "personagens conceituais". Essa leitura se iniciou com Sousa Dias (1995, p. 61-62) quando nos indicou que

personagens conceituais [...] designam [...] elementos íntimos da atividade filosófica, condições dessa atividade, os 'intercessores' do pensador, as figuras ideais de intercessão sem as quais não há pensamento, filosofia, criação de conceitos.

Esse mesmo autor nos dá, em seu texto, exemplos do que seriam alguns desses "personagens conceituais" em distintos autores, citando:

o 'demônio' para Sócrates; 'Sócrates' para Platão; o 'Homem simples' ou o 'Senhor-toda-a-gente' para Descartes; o 'Advogado de Deus' para Leibniz; o 'Inquiridor' do empirista; o 'Juiz' em Kant; o 'Nômada' em Deleuze; o 'Funcionário da Humanidade' para Husserl; o ‘Observador’ para Einstein (p. 53).

Fomos entendendo, então, que os "personagens conceituais" poderiam ser figuras, argumentos ou artefatos que nas pesquisas que desenvolvemos aparecem com aquilo/aquele com que se "conversa", permanecendo por muito tempo conosco para que possamos pensar e articular idéias, formando os conhecimentossignificações possíveis aos processos de pesquisa que desenvolvemos.

Assim, fomos percebendo que, nas pesquisas nos/dos/ com os cotidianos, as narrativas (e sons de diversos tipos) e as imagens dos praticantespensantes dos espaçostempos que pesquisávamos eram "personagens conceituais". Com eles, então, conversamos longo tempo, e vamos formulando modos de fazer e pensar nas pesquisas que desenvolvemos.

Na presente pesquisa, as imagens e sons dos filmes que vemos, bem como as "conversas" que desenvolvemos com os praticantespensantes nos cineclubes, vêm se comportando como nossos "personagens conceituais".

Nesse sentido, aplicamos, ainda uma vez, os processos que aprendemos com Certeau (1994) e que são articulados às pesquisas de Détienne ${ }^{12}$, nas quais 'dizer' e 'repetir de outro modo' são modos de pesquisar. Sobre estes processos diz Certeau (1994, p. 155):

[Détienne] não instala as histórias gregas diante de si para tratá-las em nome de outra coisa que não elas mesmas. Recusa 
o corte que delas faria objetos de saber, mas também objetos a saber, cavernas onde 'mistérios' postos em reserva aguardariam da pesquisa científica o seu significado. Ele não supõe, por trás de todas essas histórias, segredos cujo progressivo desvelamento lhe daria, em contrapartida, o seu próprio lugar, o da interpretação. Esses contos, histórias, poemas e tratados para ele já são práticas. Dizem exatamente o que fazem. São gestos que significam. [...] Formam uma rede de operações da qual mil personagens esboçam as formalidades e os bons lances. Neste espaço de práticas textuais, como num jogo de xadrez cujas figuras, regras e partidas teriam sido multiplicadas na escala de uma literatura, Détienne conhece como artista mil lances já executados (a memória dos lances antigos é essencial a toda partida de xadrez), mas ele joga com esses lances; deles faz outros com esse repertório: 'conta histórias' por sua vez. Re-cita esses gestos táticos. Para dizer o que dizem, não há outro discurso senão eles. Alguém pergunta: mas o que "querem" dizer? Então se responde: vou contá-los de novo.

Por fim, cabe lembrar, mais uma vez, de Manguel (2001) quando nos disse que são fortes a relações das imagens com as narrativas, pois umas remetem às outras o tempo todo, o que temos reconhecido nas tantas pesquisas que desenvolvemos, há muito.

\section{As 'conversas' sobre questões religiosas e racismos na pesquisa}

Na pesquisa que desenvolvemos, foram especialmente dois, os filmes vistos que possibilitaram o aparecimento de 'conversas' nos grupos dos cineclubes sobre questões religiosas, racismos e convivência religiosa: Besouro (2009; direção: João Daniel Tikhomiroff; Brasil) e O vento será tua herança (1999; direção: Daniel Petrie, EUA). O primeiro deles articula vida cotidiana e mitos, contando a história de famoso capoeirista baiano que ficou conhecido pelo nome de Besouro. O segundo trata de uma história acontecida em uma pequena cidade americana que envolve um professor do ensino médio de biologia que discute com seus estudantes a teoria evolucionista de Darwin, sofrendo um processo legal que chega a proibi-lo de dar aulas, já que, no estado em que atuava, havia uma lei que obrigava a lecionar o criacionismo nas escolas, como havia também em outros estados americanos à época ${ }^{13}$. E como, alguns desejam aplicar no Brasil nos dias de hoje! 
A dificuldade de alguns participantes de assistirem ao filme 'Besouro' foi percebida, em primeiro lugar, pela saída de um ou outro da sala de projeção, nos cineclubes, mal começaram as primeiras cenas do filme ou quando manifestações religiosas de personagens negros aparecem em cenas, dentro de uma mata. A intolerância aparece, assim, em alguns casos, no momento mesmo da projeção. Mas vai aparecer também nas 'conversas' - presenciais ou on-line - que se seguem à projeção indicada, de modo diverso: não aludindo à religião dominante entre os personagens do filme, de matriz africana; aludindo a "aspectos diferentes" dos personagens; a "exaltação" e "fortes apelos sexuais" desses personagens; muita briga ${ }^{14}$; demonstrações de força; indicação de filmes que melhor substituiriam esse para discutir religião etc.

Já na projeção do filme $O$ vento será tua herança, a visualização do processo contra o professor - com manifestações violentas contra o mesmo - permitiu o desenvolvimento de boas 'conversas' em torno das perguntas: é possível calar alguém pelas coisas que pensa? E mesmo um professor deve ser calado, em qualquer circunstância? E se as manifestações são mais silenciosas - é possível? Como convivermos harmonicamente nesses espaçostempos escolares? Essa última foi a questão central na qual nos fixamos para 'conversar' sobre as questões religiosas, hoje, nas escolas brasileiras.

É preciso ressaltar que as manifestações 'fundamentalistas' que apareceram nos cineclubes se referiam a uma minoria dos participantespensantes que assistiram a esses filmes. A grande maioria - independente de sua religião ou da falta dela - participava das 'conversas' com desejo expresso de perceber melhor a questão e poder criar condições de convivência em suas turmas ou futuras turmas, dizendo, aliás, ser esta uma questão que aparece, "cada vez mais", nos tantos dentrofora das escolas.

Não podemos e não queremos aprofundar a discussão sobre aquelas manifestações de grande intransigência que apareceram com reações que não permitiram a discussão com quem as tinha: saída da sala mal começada a projeção, por exemplo. Mas, nas "conversas" que desenvolvíamos com aqueles que, como nós, estavam preocupados com essas manifestações e outras, estampadas em jornais e mostradas na televisão, surgiram pistas interessantes sobre possibilidades de ação que nos interessavam ver discutidas.

Todos esses processos nos fizeram realizar, nas dependências da Universidade do Estado do Rio de Janeiro (UERJ), um cineclube especial com filmes africanos no qual estas discussões estiveram presentes, mas muito mais difusas, seja por- 
que os que quiseram fazer estes encontros, participando das conversas que neles surgiam, se interessavam por conhecer aspectos das 'áfricas contemporâneas', seja porque os filmes, mesmo nos permitindo identificar alguns clichês comuns a filmes ocidentais - algumas vezes invertidos - nos mostravam seres humanos com seus problemas, seus amores, suas condições de luta. Mas falaremos deste cineclube em outro artigo.

\section{Da importância das imagens e sons em filmes para a busca de convivência nas escolas}

A existência de filmes que narram experiências humanas diversas e inesgotáveis tem possibilitado que, de forma estimulante, possamos tratar das questões que estão nas tantas redes educativas que formamos e que nos formam. Sejam filmes sobre escolas, professores e estudantes - com todos os clichês que neles podemos encontrar - sejam acontecimentos narrados que mostram as possibilidades humanas de criar lindas coisas ou terríveis experiências, com a introdução de sons ou sem eles, as condições de 'conversas' após projeção se multiplicam.

No caso do segundo filme referido, O vento será sua herança, as 'conversas' surgidas surpreenderam todos os que delas participaram: para começar, a nós que formávamos o grupo de pesquisa que pudemos perceber tanto a negativa de alguns de sequer participar da discussão que propúnhamos, quanto o bom número daqueles que, angustiados com as questões que enfrentavam nas práticas escolares, gostavam muito de encontrar espaçostempos para discutir essas questões 'calmamente'. As ações a que chamamos 'fundamentalistas' do pastor no filme - com suas agressivas palavras (e o sons 'martelantes' que as acompanhavam) e seus gestos de arregimentação da população local contra o professor - serviam para exemplificar algumas práticas que já tinham visto aparecer em algumas de suas redes e com as quais não concordavam, em especial, quando dirigidas contra crianças. Surpreenderam, ainda, aos militantes do movimento de professores, pois puderam compreender que a presença de problemas existiu na vivência de outros professores, na história do movimento docente e em outros espaçostempos diferentes daqueles que vivem, no seu aqui e agora. Perceberam que os combates e as negociações precisaram acontecer sempre. Por fim, surpreenderam também aos docentes e discentes presentes nos cineclubes e que participaram das 'conversas' neles desenvolvidas, percebendo a existência de problemas religiosos em períodos diferentes da história dos professores. 
De muitos modos, essas questões surgiram também nas 'conversas' em torno do primeiro filme (Besouro). Nelas, havia uma afirmativa geral que era algo como: "é bom conhecer e poder compreender como as culturas africanas se encontraram no Brasil com sua natureza: as florestas, o clima etc”. A dificuldade de alguns participantes de assistirem ao filme "Besouro" foi percebida, em primeiro lugar, pela saída de um ou outro da sala de projeção, nos cineclubes, mal começaram as primeiras cenas do filme ou quando manifestações religiosas de personagens negros, dentro de uma floresta, apareceram em cena. Algumas afirmativas de cunho mais religioso apareceram: "é interessante perceber que a busca pelo espiritual é comum a todos os seres humanos qualquer que seja sua religião"; "voltar-se para dentro, em certos momentos das diversas cerimônias religiosas, para buscar um contato com o deus ou os deuses, é movimento encontrado em todas as religiões"; a existência de "acessórios".

Naturalmente, as diferenças também foram ressaltadas, embora em movimentos que buscavam compreendê-las: a mais comentada - talvez porque o grupo, como o magistério em geral, era majoritariamente composto por mulheres - tinha relação com as diferenças de vestimentas e de adornos. O papel do corpo exposto nas religiões de matriz africana e o corpo coberto em outras religiões. A presença do alimento a ser preparado e consumido no momento das cerimônias que se apresentavam muito diferentes nas várias religiões. A educação das crianças e as cerimônias possíveis ou não a elas foi outro aspecto sobre o qual 'conversas' foram mantidas.

Por fim, o papel de palavras "cantadas" e os diferentes instrumentos presentes, como parte das cerimônias, em suas diferenças pode ser discutida porque nos dois filmes estavam presentes.

\section{NOTAS}

1. O projeto - que tem como título "Redes educativas, fluxos culturais e trabalho docente - o caso do cinema, suas imagens e sons" - busca compreender o que estamos chamando "os mundos culturais dos docentes" e sua relação com os currículos praticadospensados nas escolas. Tem o financiamento do CNPq, FAPERJ e UERJ. Atuaram nele, em sua primeira fase, os bolsistas: Nilton Alves (AT-CNPq); Maressa Cristina Pereira dos Santos (Pibic-CNPq e IC-CNPq); Juliana Rodrigues (Pibic-UERJ e Pibic-CNPq); Izadora Agueda Ovelha (UERJ-bolsadocência); Stephanie Rocha Rei (Pibic-UERJ; IC-Faperj); Diana Silva Barros (Pibic-UERJ); Marcos Alexandre (IC-CNPq). O projeto teve também, em diferentes ocasiões apoio de pós-doutorandos, doutorandos e mestrandos do grupo de pesquisa: Marly de Jesus Silveira (UnB/ Prodoc); Maritza Maldonato (UEMG; Prodoc/CNPq); Virgínia de Oliveira Silva (UFParaíba; PNPD/Capes); Nívea Andrade (UFF); Antonio Eugênio do Nascimento; Joana Ribeiro dos Santos; Sonia Maria Santos Pereira da Rocha; Simone de Paiva Santana Guimarães. 
2. Temos trabalhado com a ideia que os termos que vimos dicotomizados pelas ciências na Modernidade precisam ser compreendidos em sua dependência uns aos outros Em relação a esses dois termos - praticantespensantes- quem propôs esta formulação foi Oliveira (2012).

3. Nas pesquisas com os cotidianos, as 'conversas' entre os/as pesquisadores/ as e os/as praticantespensantes são entendidas como o lócus necessário das pesquisas.

4. São os seguintes os filmes usados nos cineclubes, até aqui: $O$ pequeno Nicolau (2010; direção: Laurent Tirard; França); Valentin (2003;direção: Alejandro Agresti; Argentina); Besouro (2009; direção; João Daniel Tikhomiroff; Brasil); Testemunha de acusação (1957; direção: Billy Wilder; EUA); Mon Oncle (1958; direção: Jacques Tati; França); Suplício de uma alma (1956, direção: Fritz Lang; EUA); Ensaio de Orquestra (1978; direção: Federico Fellini; Itália); A Vila (2004; direção: M. Night Shyamalan; EUA); Cinema, aspirinas e urubus (2004; direção: Marcelo Gomes; Brasil); M - Vampiro de Dusseldorf (1931; direção: Fritz Lang; Alemanha); Kiriku e a feiticeira (1999; direção: Michel Ocelot; França); Cinderela em Paris (1957; direção: Stanley Donen; EUA); 180o (2011; direção: Eduardo Vaisman; Brasil); Mandela (2007; direção: Bille August; EUA); Casablanca (1942; direção: Michael Curtiz; EUA); O Artista (2011; direção:MichelHazanavicius, França); Cinema Paradiso (1988; direção: Giuseppe Tornatore, Itália); O fabuloso destino de AméliePoulain (2001; direção: Jean-Pierre Jeunet; França); Sonhos (1990; direção: Akira Kurosawa; Japão); Cantando na chuva (1952; direção: Stanley Donen; EUA); Ao mestre, com carinho (1967; direção: James Clavell, Reino Unido); O vento será tua herança (1999; direção:Daniel Petrie, EUA); Dia do pagamento (1922; direção: Charles Chaplin, EUA); Luzes da Cidade (1931; direção: Charles Chaplin, EUA); O Homem Que Sabia Demais (1956; direção: Alfred Hitchcock, EUA); O grande desafio (2007; direção: Denzel Washington, EUA).

5. Este curso de extensão foi solicitado pela Profa. Stela Guedes Caputo depois da aposentadoria de Nilda Alves - a quem agradecemos imensamente o companheirismo que permitiu desenvolver o projeto como precisávamos.

6. No que se refere à formação docente, por exemplo, temos trabalhado com a ideia de que os professores e professoras são formados em diversas redes educativas que identificamos assim: a das práticasteorias da formação acadêmica; a das práticasteorias pedagógicas cotidianas; a das práticasteorias das políticas de governo; a das práticasteorias das pesquisas em Educação; a das práticasteorias de produção e de 'uso' das mídias; a das práticasteorias de vivências nas cidades, no meio rural ou à beira das estradas.

7. Como antropólogo, Augé se refere a desafios à Antropologia, mas entendemos que elas também se estendem a todas as ciências chamadas de humanas e sociais.

8. Confessamos, também, que foi escolhido porque é um meio de que gostamos muito.

9. A distribuição de um desses folhetos em um desses fóruns, levou a que o grupo Ilé Oba Oyó, coordenado por Stela Guedes Caputo e relacionado ao Programa de Pós-Graduação em Educação (ProPEd/UERJ), abrisse um processo com vistas a proibir a circulação da cartilha, impressa durante a vinda do Papa Francisco ao Brasil, por uma fundação internacional. O processo gerou a MP do Inquérito civil n. 14/2014, da promotora Renata Scharfstein, da Promotoria de Justiça de Tutela Coletiva de Proteção à Educação da Capital, do Ministério Público do Estado do Rio de Janeiro, que mandou recolher e proibiu a circulação desse material, proibindo também a realização de outros fóruns.

10. Referimo-nos à Lei n. 10639/2003 eà Lei n. 11645/2008.

11. Maturana (1997, p. 132) diz ainda: "Chamo de conversação nossa operação nesse fluxo entrelaçado de coordenações consensuais de linguajar e emocionar e chamo de conversação as diferentes redes de coordenações entrelaça- 
das e consensuais de linguajar e emocionar que geramos ao vivermos juntos com seres humanos."

12. Historiador francês que trabalha com a civilização grega.

13. O julgamento ocorreu em 1925, no estado norte-americano do Tennessee, contra o professor Bertram T. Cates que é acusado de desrespeitar uma lei estadual que proíbe o ensino do Darwinismo em escolas públicas. O processo ficou conhecido como "Monkey Trial" (O Julgamento do Macaco) e teve repercussão mundial, mediante uma batalha travada entre os advogados de acusação e a defesa, que foi impedida pelo juiz de apresentar cientistas como testemunhas em favor da teoria da evolução. O julgamento durou 11 dias e foi o primeiro a ser transmitido pelo rádio. Dados obtidos em: https:// pt.wikipedia.org/wiki/Inherit_the_Wind_(1960), in 27.07.2015.

14. Lembramos que o filme é uma biografia - bastante onírica - de um capoerista. Logo, as brigas precisavam aparecer.

\section{Referências}

ALVES, Nilda. Redes Educativas 'dentrofora' das escolas, exemplificadas pela formação de professores. In: SANTOS, Lucíola, DALBEN, Ângela e LEAL, Júlio Diniz Leiva (Org.). Convergências e tensões no campo da formação e do trabalho docente: Currículo, Ensino de Educação Física, Ensino de Geografia, Ensino de História, Escola, Família e Comunidade. 66. ed. Belo Horizonte/MG: Autêntica, 2010, v. 1, p. 49-66.

. Decifrando o pergaminho - os cotidianos das escolas nas lógicas das redes cotidianas. In: OLIVEIRA, Inês Barbosa de e ALVES, Nilda. Pesquisa nos/dos/com os cotidianos das escolas. Petrópolis/RJ: DPetAlii, 2008. p. 15-38.

AUGÉ, Marc. Pour une anthropologie des mondes contemporains. Paris: Flammarion, 1997.

BORGES, Jorge Luiz. Prólogo. In: BORGES, Jorge Luiz e FERRARI, Osvaldo. Sobre a filosofia e outros diálogos. S. Paulo: Hedra, 2009.

COUTINHO, Eduardo. O cinema documentário e a escuta sensível da auteridade. In: ANTONACCI, Maria Antonieta e PERELMUTTER, Daisy (Org.). Projeto História - ética e história oral. S. Paulo: PUC/SP, abr./97, (15), p. 165-191.

DELEUZE, Gilles; GUATTARI, Félix. O que é filosofia? Rio de Janeiro: Editora 34, 1992.

ELIAS, Norbert. A sociedade dos indivíduos. Rio de Janeiro: Jorge Zahar, 1994.

GALLO, Silvio; VEIGA NETO, Alfredo (Org.). Fundamentalismo E Educação. Belo Horizonte: Autêntica, 2009. 
GONÇALVES, Marco Antonio e HEAD, Scott (Org.). Devires imagéticos - a etnografia, o outro e suas imagens. Rio de Janeiro: 7 Letras/FAPERJ, 2009.

LARROSA, Jorge. Pedagogia profana: danças, piruetas e mascaradas. Belo Horizonte: Autêntica, 1999.

MANGUEL, Alberto. Lendo imagens. S. Paulo: Companhia das Letras, 2001.

MATURANA, Humberto. Cognição, ciência e vida cotidiana. Belo Horizonte/MG: Ed UFMG, 2001.

OLIVEIRA, Inês Barbosa. Currículos e pesquisas com os cotidianos: o caráter emancipatório dos currículos 'pensadospraticados' pelos 'praticantespensantes' dos cotidianos das escolas. In: Carlos Eduardo Ferraço e Janete Magalhães Carvalho (Org.). Currículos, pesquisas, conhecimentos e produção de subjetividades. 1ed. Petrópolis: DP et Alli, 2012, p. 47-70.

SOUSA DIAS. Lógica do acontecimento. Porto: Afrontamento, 1995 .

Recebido em: 04/o8/15

Aceito em: 04/09/15

\section{NILDA ALVES}

Licenciatura e bacharelado em Geografia pela Universidade do Brasil. Doutorado em Sciences de l'Éducation/Sociologie, pela Université de Paris V (René Descartes), em 1981. Pós-doutorado no INRP/Ministère de l'Éducation/França, em 1988. Professora titular aposentada da Universidade do Estado do Rio de Janeiro (UERJ), com contrato de pesquisadora visitante (2012-2014; 2014-2017). Pesquisadora 1 A/CNPq. Líder do GRPesq “Currículos, redes educativas e imagens", vinculado ao Laboratório Educação e Imagem/ProPEd/UERJ. 


\section{ALESSANDRA CALDAS}

Possui Doutorado e Mestrado em Educação, pelo Programa de PósGraduação em Educação da Universidade do Estado do Rio de Janeiro (UERJ). Pós-doutoranda no Proped/UERJ, orientada pela Profá. Nilda Alves, com bolsa Capes/FAPERJ, membro do GRPesq "Currículos, redes educativas e imagens”, vinculado ao Laboratório Educação e Imagem/ ProPEd/UERJ.

\section{ÉRIKA ARANTES}

Pós-Doutora em Educação pela Universidade do Estado do Rio de Janeiro (UERJ). Doutora em História pela Universidade Federal Fluminense (UFF) e Mestre em História pela Universidade Estadual de Campinas (UNICAMP). Membro do Laboratório Educação e Imagem (Proped/ UERJ) onde desenvolve pesquisas relacionadas às questões raciais e ao cinema e educação, com ênfase no cinema africano. Professora da Secretaria de Educação do Estado do Rio de Janeiro no município de Nova Iguaçu e do município do Rio de Janeiro. 


\section{REBECA BRANDÃO}

Doutoranda em Educação pelo Programa de Pós-Graduação em Educação na Universidade do Estado do Rio de Janeiro (Proped/UERJ), Mestre em Educação pela mesma Universidade. Membro do GRPesq "Currículos, redes educativas e imagens", vinculado ao Laboratório Educação e Imagem/ ProPEd/UERJ. Professora da rede municipal do Rio de Janeiro.

\section{ISABEL MACHADO}

Doutoranda em Educação pelo Programa de Pós-Graduação em Educação na Universidade do Estado do Rio de Janeiro (Proped/UERJ), Mestre em Educação pelo Proped/UERJ, Especialista em Gênero e Sexualidade pelo Instituto de Medicina Social/UERJ. Integrante do GRPesq "Redes educativas, currículos e imagem", vinculado ao Laboratório Educação e Imagem/ProPEd/UERJ. 